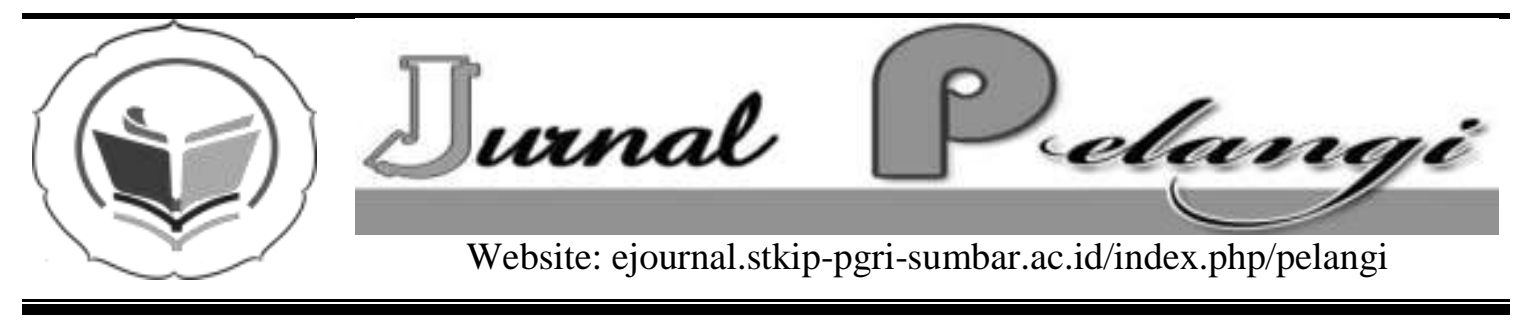

\title{
KOMPOSISI FITOPLANKTON YANG TERDAPAT DI PERAIRAN BATANG PALANGKI KABUPATEN SIJUNJUNG
}

\section{Rina Widiana}

INFO

ARTIKEL

Diterima:

Direview:

Disetujui:

\section{Keywords:}

Water

pollution, composition, phytoplankton

\begin{tabular}{l} 
Abstract \\
Phytoplankton is water plant which floats freely and float away in \\
water and able to photosynthesis. Phytoplankton has important \\
role since it become food for animals are life in that water, such as \\
fish and insect. Morever, phytoplankton is able to influence the \\
quality of water. There are some houses, livestock market and \\
farmland. Water of Batang Palangki river is used to fulfill daily \\
needs, means of gold mining, sand, bathing place for livestock and \\
fish catching. A research has been done in Batang Palangki river. \\
Its purpose is to know the phytoplankton composition in Batang \\
Palangki river. This research was conducted by using descriptive \\
survey method which chose four research stations that is station I \\
settlement area, station II farm, station III gold mining area and \\
station IV post area of gold mining. Sample was selected in 3 spots \\
for each station, namely left, right and center of river. Parameter \\
which was measured was abundance, relative density, frequency \\
and relative frequency, and quality parameter of water which was \\
measured was temperature, pH, the flow of speed, DO, and CO2. \\
From the result of this research, it was found that the \\
phyotoplankton composition was 4 classes, 4 ordo, 9 families and \\
13 genus. Total abundance was 24,68 individu/l, abundance is \\
highest in station II was 8,34 individu/l, and then station I was 7,98 \\
individu/l, station IV was 4,93 individu/l and station III was 3,43 \\
individu/l. Class that highest abundance was Bacillariophyceae, \\
was 16,55 individul and minimal low was Euglenophyceae, was \\
0,46 individu/l. Genus that highest abundance was Navicula, was \\
4,78 individu/l and minimal low was Phacus was 0,46 individu/l. \\
\hline
\end{tabular}

\section{Abstract}

Phytoplankton is water plant which floats freely and float away in water and able to photosynthesis. Phytoplankton has important fish and insect. Morever, phytoplankton is able to influence the quality of water. There are some houses, livestock market and farmland. Water of Batang Palangki river is used to fulfill daily needs, means of gold mining, sand, bathing place for livestock and fish catching. A research has been done in Batang Palangki river. Its purpose is to know the phytoplankton composition in Batang Palangki river. This research was conducted by using descriptive survey method which chose four research stations that is station I settlement area, station II farm, station III gold mining area and station IV post area of gold mining. Sample was selected in 3 spots for each station, namely left, right and center of river. Parameter which was measured was abundance, relative density, frequency and relative frequency, and quality parameter of water which was measured was temperature, $\mathrm{pH}$, the flow of speed, $\mathrm{DO}$, and $\mathrm{CO}$. From the result of this research, it was found that the phyotoplankton composition was 4 classes, 4 ordo, 9 families and 13 genus. Total abundance was 24,68 individu/l, abundance is highest in station II was 8,34 individu/l, and then station I was 7,98 individu/l, station IV was 4,93 individu/l and station III was 3,43 individur. Class that highest abundance was Bacillariophyceae, 0,46 individu/l. Genus that highest abundance was Navicula, was 4,78 individu/l and minimal low was Phacus was 0,46 individu/l. 


\section{PENDAHULUAN}

Fitoplankton adalah organisme yang hidup melayang dan hanyut dalam air serta mampu berfotosintesis (Nybakken, 1992). Fitoplankton merupakan tumbuhan yang mengandung pigmen klorofil dan mampu melaksanakan reaksi fotosintesis. Keberadaan Fitoplankton dalam lingkungan perairan mempunyai arti yang penting karena Fitoplankton merupakan rantai makanan pertama dalam penyediaan energi bagi kehidupan dalam air (Djuhanda, 1980). Fitoplankton disebut juga sebagai produsen primer, karena merupakan pangkal rantai pakan dan fondamen yang mendukung kehidupan seluruh biota laut lainnya (Nontji, 1993)

Selain itu Fitoplankton juga dapat dijadikan sebagai indikator biologis dalam pencemaran air sungai. Bila keanekaragaman Fitoplankton di ekosistem tinggi menandakan kualitas air baik dan bila keanekaragaman Fitoplankton sedikit menandakan air tercemar (Sastrawijaya, 1991). Fitoplankton terdiri dari alga, yaitu kelompok organisme yang termasuk ke dalam divisi Thallophyta. Tujuh kelas yang ada dalam divisi tersebut, kebanyakan hidup sebagai plankton, perifiton dan bentos. Kelas yang bersifat plankton adalah Clorophyceae, Cyanophyceae, Euglenophyceae, Chrysophyceae dan Phyrophyeae (Dinoflagelata), sedangkan Phaeophyceae dan Rhodophyceae sebagai rumput laut. Penentuan jenis Fitoplankton tergantung pada warna atau pigmen yang dikandungnya. Kelas yang hidup sebagai Fitoplankton adalah
Chlorophyceae, Cyanophyceae, Euglenophyceae, Chrysophyceae dan Bacillariophyceae (Sachlan, 1974) Chlorophyceae merupakan ganggang hijau. mempunyai kloroplas yang mengandung klorofil a, klorofil $b$ dan karotinoid. Chlorophyceae terdiri dari selsel kecil yang membentuk koloni berupa benang bercabang atau tidak bercabang, ada juga membentuk koloni yang menyerupai kormus tumbuhan tinggi. Alga ini biasa hidup dalam air tawar dan terdiri dari banyak ordo, yaitu Chlorococcales, Ulotrichales, Cladoporales, Volvocales dan Conjugales (Tjitrosoepomo, 1981). Adapun contoh genus dari masingmasing ordo tersebut adalah: 1) contoh genus Chlorococcales, Pediastrum dan Clorococcum, 2) Ulotrichales, Ulothrix, 3) Cladoporales, Cladopora, 4) Volvocales, Poliblepharides, Clamidomonas dan Volvox dan 5) Conjugales, Clostridium, Desmidium, Spyrogira, Mougeotla dan Zygnema (Tjitrosoepomo, 1981).

Cyanophyceae banyak ditemukan pada perairan yang tercemar berat, terutama pada pembuangan limbah industri yang kurang mendapat cahaya matahari. Cyanophyceae terdiri dari + 150 spesies yang berasal dari beberapa family, yaitu Oscilatoriaceae, Nostacaceae, Rivulariaceae, Chroococeae, Notochopcideae dan Scytonemataceae (Sachlan, 1974). Famili yang umum ditemukan di perairan adalah Oscillatoriaceae, Nostocaceae, Rivulariaceae dan Chrooceae. Adapun contoh genus dari masing-masing family tersebut adalah: 1) family Oscilatoriaceae, Oscilatoria, 2) 
Nostocaceae, Nostoc dan Anabena, 3)

Rivulariacea, Rivularia dan 4) Chroococeae, Chroococus dan Glueocapsa (Sachlan, 1974).

Kelas Euglenophyceae, $90 \%$ dari anggotanya hidup dalam air tawar yang banyak terdapat organik matter. Pada permukaan perairan yang tidak bergerak, beberapa dari dari golongan Euglenophyceae dapat membentuk cysta yang menutupi seluruh perairan dan berwarna merah, hijau, kuning atau kombinasi dari warna-warna tersebut (Sachlan, 1974). Euglenophyceae memiliki famili Euglenaceae dengan contoh genusnya Euglena. Hidup dalam air tawar, kolam atau tempat-tempat yang berlumpur. Chrysophyceae memiliki tiga genus, yaitu: 1) Cocolith, genus ini belum lama diketahui karena sangat kecil, berdinding kapur dan terdapat di dasar laut yang tidak begitu dalam. 2) Synura, merupakan koloni kecil yang terdiri dari selsel yang berflage 1. 3) Chrysamoeba, bentuknya seperti amoeba yang dapat mengambil makanan seperti Rhizopoda. Mempunyai sedikit klorofil dan hidup seperti spesiesspesies yang holopytik (Sachlan, 1974).

Bacillariophyceae atau Diatomae disebut juga dengan ganggang kersik, berupa jasad renik bersel satu yang masih dekat dengan Flagellatae. Diatomae hidup dalam air tawar maupun dalam air laut, serta di atas tanah-tanah yang basah terpisah-pisah atau membentuk koloni. Tahan hidup di atas tanah dengan kondisi yang buruk (kekeringan) sampai beberapa bulan. Bacilliriophyceae atau Diatom dibagi menjadi 2 ordo, yaitu: 1) Centralles, contoh genusnya Biddulphia, Dytilium, Melosira dan Bacteriostrum. 2) Pennales, contoh genusnya Flagilaria, Navicula, Gomphonema, Cymbella, Surirella, Synedra, Gyrosigma dan Pinnularia (Tjitrosoepomo, 1981).
Kehidupan fitoplankton dalam perairan dipangaruhi oleh kondisi dari beberapa faktor fisika kimia perairan. Adapun faktor fisika kimia yang cenderung mempengaruhi kehidupan fitoplankton adalah: suhu, kecepatan arus, $\mathrm{CO} 2$ bebas, pH dan DO (Suin, 2002). Suhu merupakan faktor pembatas terhadap pertumbuhan dan penyebaran suatu spesies, karena suhu mempengaruhi metabolisme dalam tubuh spesies tersebut. Suhu optimum untuk pertumbuhan plankton berkisar antara 26-27o C(Methew, 1975 dalam Fitri, 2006).

Pergerakan fitoplankton sangat dipengaruhi oleh arus. Kecepatan arus pada sungai dikelompokkan atas tiga kategori, yaitu cepat, bila kecepatan arus berkisar antara 0,5-1 m/dt, sedang bila kecepatan arus berkisar antara 0,25-0,49 $\mathrm{m} / \mathrm{dt}$ dan lambat bila kecepatan arus berkisar antara 0,1-24 m/dt (Welch, 1980). Karbondioksida dihasilkan dari proses pernafasan organisme baik hewan maupun tumbuhan. Perairan yang mengalami proses dekomposisi yang cepat akan menghasilkan kandungan $\mathrm{CO} 2$ yang tinggi dan kekurangan oksigen. Kandungan karbondioksida yang tinggi di dalam perairan dapat menyebabkan kematian bagi hewan (Anonimus, 2006). Menurut Sukmeri (2002) derajat keasaman menunjukkan konsentrasi ion $\mathrm{H}+$ dalam larutan. $\mathrm{pH}$ air yang memenuhi syarat untuk kehidupan organism berkisar antara 6,5-8. Perubahan $\mathrm{pH}$ badan air sangat menganggu kehidupan tumbuhan, hewan dan organisme pengurai yang hidup di dalam badan air tersebut (Moersidik, 1998). pH optimum untuk kehidupan plankton berkisar antara 5,5-8,5 (Welch, 1980). 
Menurut Suharsono (1990 dalam Lisanty, 2000) kadar oksigen terlarut minimum yang dibutuhkan untuk mendukung kehidupan organisme akuatik secara normal adalah 2 ppm dengan catatan di dalam perairan tidak terdapat persenyewaan beracun. Menurut Sastrawijaya (1991) Fitoplankton dan zooplankton berenang dalam perairan. Fitoplankton memiliki siklus hidup pendek sehingga cepat sekali memberi reaksi terhadap perubahan kualitas air yang disebabkan oleh pencemaran. Dampak pencemaran dapat mempengaruhi perubahan struktur dan fungsi ekosistem sungai, baik hewan maupun tumbuhan. Banyaknya bahan pencemar dalam perairan akan mengurangi keanekaragaman organisme dan pada umumnya akan meningkatkan populasi jenis yang tahan terhadap kondisi perairan tersebut. Indikator biologi digunakan untuk menilai secara makro perubahan keseim-bangan ekologi khususnya ekosistem akibat pengaruh limbah (Hawkes, 1975 dalam Sastrawijaya, 1991).

Tingkat pencemaran sungai dapat dilihat dari keanekaragaman atau diversitas dan laju pertumbuhan struktur dari plankton. Jika keanekaragaman plankton di ekosistem tinggi menandakan kualitas air tersebut baik, tetapi jika keanekaragaman plankton tersebut sedikit maka menandakan airnya tercemar (Sastrawijaya, 1991). Salah satu sungai yang terdapat di kabupaten Sijunjung adalah Batang Palangki. Sungai ini tidak dapat dipisahkan dari kehidupan masyarakat Palangki. Sungai ini terletak di sepanjang pemukiman penduduk dengan panjang $+30 \mathrm{~km}$ dan lebar $+20 \mathrm{~m}$. Di sepanjang daerah aliran sungai banyak aktivitas yang dilakukan oleh penduduk dan aktivitas tersebut telah menyebabkan air sungai keruh dan kondisi ini memungkinkan terjadinya pence-maran sungai. Adapun aktivitas masyarakat tersebut adalah penambangan emas, rumah tangga dan pertanian, sehingga mengakibatkan penurunan kualitas air dan perubahan ekosistem. Perubahan ekosistem sungai dapat menyebabkan kepunahan jenis-jenis organisme tertentu, sehingga keragaman dalam ekosistem sungai berkurang. Berdasarkan penelitian Gumsi (2004) air Batang Palangki dinyatakan sudah tercemar oleh aktivitas penambangan, tetapi masih memenuhi standar kualitas air untuk kelas III yang diperuntukkan bagi pertanian dan peternakan. Dari penelitian tersebut didapatkan kadar logam merkury total yang tersuspensi dalam air sudah melebihi ambang batas yang diperbolehkan. Berdasarkan masalah tersebut, maka dilakukan penelitian dengan tujuan untuk mengetahui komposisi Fitoplankton yang terdapat di perairan Batang Palangki Kabupaten Sijunjung.

\section{METODE PENELITIAN}

Penelitian ini dilaksanakan pada Agustus 2009 di Batang Palangki Kabupaten Sijunjung. Identifikasi sampel Fitoplankton dilakukan di Laboratorium Biologi STKIP PGRI Sumatera Barat Padang dan pengukuran faktor fisikakimia air dilaksanakan di Balai Laboratorium Kesehatan (BLK) Padang. Penelitian ini dilakukan dengan survey deskriptif dan pengambilan sampel dilakukan pada empat stasiun. Penetapan stasiun secara purposive sampling, yaitu: berdasarkan pada variasi kondisi sungai. Stasiun I berada pada daerah aliran yang menjadi pemukiman penduduk, Stasiun II pada areal pertanian, Stasiun III pada lokasi penambangan emas dan Stasiun IV pada aliran sungai sesudah penambangan emas. Pengambilan sampel pada masingmasing stasiun dilakukan pada 3 titik, 
yaitu di bagian sisi kiri, tengah dan bagian kanan badan sungai.

\section{Cara Kerja}

1. Pengambilan

Sampel

Fitoplankton Sampel air diambil sebanyak 100 liter dan disaring dengan net plankton no.25. Sampel diawetkan dengan formalin $4 \%$ sebanyak $1 \mathrm{ml}$. Pengambilan sampel dilakukan satu kali pada pukul 09.00-10.00 WIB.

2. Pengukuran Fisikokimia Air Pengukuran dilakukan pada pukul 09.00 WIB, suhu dengan menggunakan Thermometer $\mathrm{Hg}$, $\mathrm{pH}$ menggunakan $\mathrm{pH}$ meter, kecepatan arus dilakukan secara konvensional dengan menggunakan gabus, $\mathrm{CO} 2$ bebas dan DO menggunakan metoda titrasi (Suin, 2002).

3. Identifikasi dan Penghitungan Jumlah Individu Fitoplankton Identifikasi sampel dilakukan sampai tingkat genus dengan menggunakan buku acuan, Prescott (1961) dan Sachlan (1974) serta penghitungan individu dengan menggunakan metode Direct Count.

\section{Parameter}

Parameter yang diukur adalah: a) komposisi, yang meliputi kerapatan, kerapatan relatif, frekuensi dan frekuensi relatif dan b) kualitas fisika dan kimia perairan yang meliputi suhu, $\mathrm{pH}$, kecepatan arus, DO dan $\mathrm{CO} 2$ bebas.

\section{Analisis Data}

Kelimpahan dihitung dengan menggunakan rumus (Michael, 1984), frekuensi, kerapatan dan frekuensi relative menggunakan rumus (Suin, 2002) dan korelasi jenjang Sperman menggunakan rumus (Sudjana, 1992).

\section{PEMBAHASAN}

Komposisi Fitoplankton di Batang Palangki Kabupaten Sijunjung terdiri dari 4 kelas, 4 ordo, 8 famili dan 13 genus (Tabel 1 dan Lampiran 1) dan kualitas fisika kimia air Batang Palangki masih masuk dalam kisaran normal (Tabel 2).

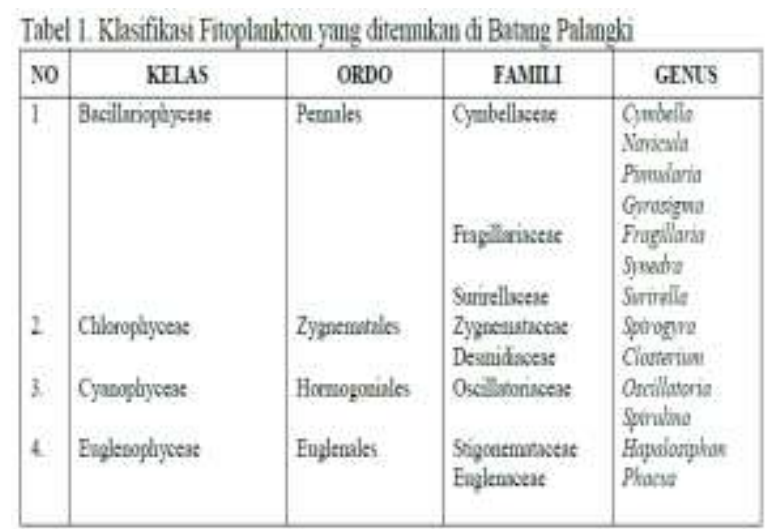

\begin{tabular}{|c|c|c|c|c|c|}
\hline No & Parameter & Stasime I & Stasiun [] & Seasinn III & Susim IV \\
\hline 1 & Sutur( $C$ & 28 & 25 & 25 & 27 \\
\hline 2 & Kec. Arss (mulfi) & 0,56 & 0,51 & 0,0 & 0,58 \\
\hline 3 & $\mathrm{pH}$ & 6.8 & 6.7 & 6.9 & 69 \\
\hline 4 & $\mathrm{CO}_{2}$ Betas (mg l) & 5,0 & $6 !$ & 5,0 & 50 \\
\hline 5 & $D O(m g 1)$ & 6,7 & 6,9 & 73 & 69 \\
\hline
\end{tabular}

Dari Tabel 1 di atas dapat dilihat bahwa dari keempat stasiun pengamatan ditemukan empat kelas Fitoplankton yang terdiri dari 4 ordo, 8 famili dan 13 genus. Kelas Fitoplankton yang ditemukan adalah kelas Cyanophyceae yang terdiri dari 3 genus (Oscillatoria, Spirulina dan Hapalosiphon). Kelas Bacillariophyceae yang terdiri dari 7 genus (Cymbella, Navicula,Pinnularia, Gyrosigma, Flagillaria, Synedra dan Surirella) dan kelas Euglenophyceae terdiri dari genus Phacus. Menurut Sachlan (1974) keempat kelas ini merupakan kelas Fitoplankton yang biasanya ditemukan di perairan air tawar. Dari Lampiran 1 dapat dilihat bahwa total kelimpahan Fitoplankton yang ditemukan di Batang Palangki adalah 24,68 individu/liter. Kelimpahan fito plankton yang didapatkan ini 
termasuk rendah dan berdasarkan hal tersebut perairan Batang Palangki termasuk kriteria perairan kurang subur. Hal ini sesuai dengan klasifikasi perairan yang dikemukakan Prescott (1961) bahwa suatu perairan diklasifikasikan oligotrof (kesuburan rendah) bila kelimpahan individu fitoplanktonnya kecil dari puluhan ribu individu/liter, mesotrof (kesuburan sedang) bila kelimpahan besar dari puluhan ribu sampai ratusan ribu individu/liter dan eutrof (sangat subur) bila kelimpahan Fitoplankton jutaan individu/liter.

Selain itu Michael (1984) juga menyatakan bahwa perairan dikatakan kurang subur jika jumlah individu fitoplankton yang hidup dalam perairan tersebut kurang dari 50.000 individu/liter. Rendahnya kelimpahan fitoplankton di perairan Batang Palangki disebabkan karena kondisi lingkungan perairan tidak mendukung kehidupan Fitoplankton dengan baik. Terjadinya hal ini diduga karena perairan Batang Palangki sudah tercemar oleh berbagai limbah yang berasal dari aktivitas manusia yang berlangsung di perairan maupun di daerah aliran (pinggiran) Batang Palangki, seperti limbah pemukiman, pertanian, penambangan emas, penggalian batu dan pasir serta aktivitas lainnya.

Dilihat dari hasil pengukuran faktor fisiko kimia (Tabel 2), semua faktor tersebut masih berada dalam kisaran yang cocok untuk kehidupan fitoplankton. Suhu berkisar antara 2628o C dan angka ini masih masuk kisaran suhu normal perairan untuk daerah tropis, yaitu 23-32o C (Nybakken, 1992). pH berkisar 6,7-6,9 dan masih termasuk kisaran optimum untuk kehidupan plankton, yaitu 5,5-8,5 (Welch, 1980). DO berkisar antara 6,77,3 ppm dan angka ini juga masih memenuhi syarat minimum DO untuk kehidupan dalam air, yaitu 5 ppm
(Sastrawijaya, 1991). Kandungan CO2 bebas berkisar antara 5-6,2 ppm dan kandungan ini cukup untuk mendukung kelangsungan proses fotosintesis bagi kehidupan fitoplankton. Menurut Barus (2002) bahwa CO2 digunakan untuk fotosintesis mikroorganisme dan tumbuhan air. Dilihat dari kualitas fisika kimia yang diukur, perairan Batang Palangki masih berada dalam kondisi yang normal untuk kehidupan organisme perairan. Berdasarkan kenyataan ini, menunjukkan rendahnya kelimpahan fitoplankton di perairan tersebut disebabkan oleh faktor lain yang belum terukur. Faktor lain yang diperkirakan adalah kandungan merkuri dalam perairan. Hal ini diperkirakan karena sebagian besar badan perairan dari Batang Palangki ini dimanfaatkan masyarakat sebagai tempat penambangan emas, serta hal ini juga didukung oleh hasil penelitian Gumsi (2004) yang mendapatkan kandungan merkuri perairan Batang Palangki sebesar $0,0576 \mathrm{mg} / \mathrm{l}$ dan angka ini sudah melewati ambang batas yang diperbolehkan. Kelimpahan tertinggi terdapat pada stasiun II, yaitu 8,34 individu/liter dengan jumlah 13 genus, kemudian diikuti oleh Stasiun I, 7,98 individu/liter, Stasiun IV 4,93 individu/liter dan terendah pada stasiun III, 3,34 individu/liter.

Tingginya kelimpahan pada stasiun II dibanding dengan stasiun lainnya diduga karena pada stasiun ini dekat dengan lahan pertanian dan perkebunan penduduk, sehingga memungkinkan masuknya pupuk dan limbah organik ke sungai, dengan demikian akan terjadi peningkatan unsur hara dalam perairan sehingga dapat memacu pertumbuhan fitoplankton yang ada pada perairan tersebut. Menurut Goldman dan Horne (1983) aktivitas manusia juga ikut mempengaruhi kehidupan fitoplankton seperti 
pemanfaatan lahan pertanian dan pemakaian pupuk dapat meningkatkan jumlah individu dari fitoplankton. Selanjutnya Sastrawijaya (1991) menyatakan bahwa pupuk yang berasal dari limbah pertanian akan dapat memacu pertumbuhan fitoplankton dan tumbuhan air lainnya. Selain itu Jangkaru (2000) menyatakan bahwa tinggi rendahnya konsentrasi unsur hara dalam perairan akan menentukan tingkat kelimpahan fitoplankton dalam perairan tersebut.

$$
\text { Tingginya }
$$

kelimpahan

Fitoplankton pada Stasiun II juga disebabkan karena permukaan perairan pada stasiun ini cukup terbuka dibanding stasiun lainnya serta airnya lebih jernih, sehingga badan air mendapat cahaya matahari yang cukup sampai ke dasar perairan dan cahaya matahari ini sangat dibutuhkan oleh fitoplankton untuk fotosintesis. Menurut Nybakken (1988) fotosintesis hanya dapat berlangsung bila intensitas cahaya yang sampai ke suatu sel alga lebih besar dari suatu intensitas cahaya tertentu dan laju fotosintesis akan tinggi bila intensitas cahaya tinggi dan menurun bila cahaya menurun. Kelimpahan kedua tertinggi ditemukan pada Stasiun I, yaitu 7,98 individu/liter (Lampiran 1). Hal ini disebabkan karena Stasiun I berada di lokasi pemukiman penduduk dan pasar serta sungai dimanfaatkan penduduk untuk MCK dan pembuangan limbah rumah tangga dan pasar sehingga memungkinkan masuknya detergen, kotoran hewan dan limbah organik lainnya yang dapat menjadi menjadi sumber zat-zat hara yang mendukung kehidupan Fitoplankton. Zat-zat hara yang berasal dari limbah domestik seperti detergen dapat digunakan oleh fitoplankton karena detergen mengandung fosfat yang sangat dibutuhkan untuk pertumbuhan fitoplankton (Sachlan, 1974). Dimana masyarakat disana juga memanfaatkan sungai sebagai tempat pemandian dan tempat pencucian. Kelimpahan terendah ditemukan pada Stasiun III, yaitu 3,43 individu/liter (Lampiran 1). Hal ini diduga karena kondisi lingkungan perairan tidak mendukung kehidupan fitoplankton karena Stasiun III berada pada daerah yang aktivitas penambangan emas paling tinggi dari stasiun yang lain, sehingga diperkirakan kadar merkurinya tinggi dan dapat mengganggu kehidupan fitoplankton. Dugaan ini diperkuat oleh hasil penelitian Gumsi (2004) yang mendapatkan kandungan merkuri perairan Batang Palangki yang berada disekitar penambangan emas sudah mencapai 0,0576 $\mathrm{mg} / \mathrm{l}$ dan angka ini sudah melampaui ambang batas yang diperbolehkan. Genus yang memiliki kelimpahan tertinggi dari empat stasiun penelitian adalah Navicula dari kelas Bacillariophyceae. Tingginya kelimpahan dari Navicula disebabkan karena genus ini mampu bertahan hidup pada kondisi yang buruk atau tempattempat yang telah mengalami pencemaran seperti limbah rumah tangga, limbah pertanian dan zat kimia lainnya. Seperti yang dikemukakan Lisanti (2000) bahwa kelas Bacillariophyceae merupakan kelompok alga yang mudah beradaptasi dengan lingkungan dan penyebarannya luas, serta merupakan bagian terpenting dari organisme air karena merupakan makanan bagi zooplankton atau hewan air lainnya. Selain itu Sachlan (1974) dan Tjitrosoepomo (1981) menyatakan bahwa Navicula ini toleran terhadap perubahan lingkungan dan selalu ada dalam perairan bersih sampai tercemar berat.

Frekuensi tertinggi juga diperoleh oleh genus Bacillariophyceae. Pennak (1978 dalam Fitri 2006) juga menyatakan bahwa genus yang mempunyai frekuensi tertinggi berarti genus tersebut umum ditemukan dalam 
perairan. Genus yang paling sedikit ditemukan adalah Phacus dari kelas Euglenophyceae yang hanya ditemukan di stasiun I dan II. Hal ini diduga karena genus ini lebih menyukai hidup pada perairan yang relatif bersih. Rendahnya kelimpahan dari genus Phacus juga diduga karena genus ini tidak mampu bertahan dan menyesuaikan diri pada lingkungan terutama pada perairan tercemar berat seperti pada lokasi penambangan emas. Menurut Barus (2002) bahwa tercemar suatu perairan itu ditandakan adanya spesies tertentu yang mampu bertahan hidup pada kondisi tertentu.

\begin{tabular}{|c|c|c|c|c|}
\hline $\mathrm{N}_{0}$ & Kuthasi & Thes: & I weted & Kesimpulan \\
\hline 1 & Sasim I dar II & 0.851 & 0,484 & Beilocelasi nyata \\
\hline 2 & Stasim I das III & 0.874 & 0,484 & Betkcebsi ayzts \\
\hline 3 & Stasim I danIV & 0,794 & 0,484 & Betkretaci uyza \\
\hline 4 & Stasim II dan III & 0,898 & 0,484 & Berkocelasi nyzan \\
\hline 5 & Srasimn II dan IV & $0,50 \mathrm{I}$ & 0,484 & Betkotast ijuta \\
\hline 6 & Stasimu III dan IV & 0.858 & 0,44 & Betcoelas areng \\
\hline
\end{tabular}

Dari Tabel 3 di atas berdasarkan uji korelasi Jenjang Spearman diperoleh rhitung lebih besar dari rtabel dimana korelasi antar stasiun penelitian berkorelasi nyata. Hal ini menandakan bahwa keempat stasiun pengamatan saling berhubungan. Hal ini mungkin disebabkan oleh kondisi lingkungan yang relatif sama.

\section{KESIMPULAN}

Dari hasil penelitian yang telah dilkukan, dapat disimpulkan bahwa: komposisi fitoplankton terdiri dari 4 kelas, 4 ordo, 9 famili dan 13 genus. Kelimpahan total fitoplankton adalah 24,68 individu/liter, dengan kelimpahan tertinggi pada kelas Bacillariophyceae, yaitu 16,55 individu/liter dan terendah kelas Euglenophyceae yaitu 0,46 individu/liter. Frekuensi yang tinggi didapatkan dari genus Oscillatoria, Hapalosiphon, Sprirogyra, Closterium, Cymbella, Navicula, Fragillaria,
Pinnularia dan Synedra dan frekuensi yang rendah dari genus Spirulina, Gyrosigma, Surirella dan Phacus Perairan Batang Palangki termasuk kriteria perairan kurang subur. Kualitas fisika kimia perairan masih berada dalam kisaran normal untuk kehidupan organism perairan.

\section{DAFTAR PUSTAKA}

Anonimus 2006. Modul Penuntun Pratikum Ekologi Perairan, Jurusan Biologi FMIPA Universitas Andalas Padang

Barus, A. 2000. Pengantar Limnology. USU. Medan

Djuhanda, Tatang. 1980. Kehidupan Dalam Setetes Air dan Beberapa Parasit Pada Manusia. ITB. Bandung

Fitri, Y. 2006. Komposisi Fytoplankton di Batang Agam Kota Payakumbuh. Skripsi Sarjana Pendidikan Biologi PMIPA STKIP PGRI Sumatrea Barat, Padang

Goldman, C.R, A.J.Horne, 1983. Limnology. M.C.Graw-hill Book Company Inc, London

Gumsi, E.P. 2004. Analisa Fisika Kimia Batang Palangki Kecamatan IV Nagari Kabupaten Sawahlunto Sijunjung Skripsi Sarjana Pendidikan Biologi PMIPA STKIP PGRI Sumatera Barat, Padang

Jangkaru, Z. 2000. Pembesaran Ikan Air Tawar Diberbagai Lingkungan Pemeliharaan. Penebar Swadaya. Jakarta.

Lisanti. 2000. Distribusi Plankton Disungai Jujuhan Desa Batu Kangkung Taman Nasional Kerinci Seblat Kabupaten Sawahlunto Sijunjung Propinsi Sumatera Barat. Skripsi Fakultas Perikanan Universitas Bung Hatta Padang. 
Michael, P. 1984. Metode Ekologi Untuk Penyelidikan Ladang dan Laboratorium UI. Press. Jakarta.

Moersidik, S. dan Hardjojo, 1998. Analisa dan Kualitas Air. Karunika. Jakarta

Nontji, A. 1993. Laut Nusantara. Djambatan, Jakarta.

Nybakken, J.W. 1992. Biologi Laut. Suatu Pendekatan Ekologis Gramedia, Jakarta.

Prescott, G.W. 1975. Algae Western Great Lake Area. WM.C.Brow Company Pulishers. Dubuque. Iowa. 